\title{
PREVENCIJA I RANO OTKRIVANJE KARCINOMA DEBELOG CRIJEVA U VRIJEME PANDEMIJE COVID-19
}

\author{
Darjan Franjić, ${ }^{1,2}$, Inga Marijanović1 ${ }^{1,2}$ \\ ${ }^{1}$ Klinika za onkologiju, Sveučilišna klinička bolnica Mostar \\ ${ }^{2}$ Fakultet zdravstvenih studija Sveučilišta u Mostaru \\ 88000 Mostar, Bosna i Hercegovina
}

Rad je primljen 02.09.2020.. Rad je recenziran 14.09.2020. Rad je prihvaćen 19.10.2020.

\section{SAŽETAK}

UVOD: Visoki stupanj mortaliteta od karcinoma debelog crijeva ukazuje na važnost prevencije i ranog otkrivanja ove bolesti. Pojava pandemije koronavirusne bolesti 2019 (engl. Coronavirus disease 2019, COVID-19) diljem svijeta predstavlja izazov za provedbu programa ranog otkrivanja karcinoma debelog crijeva.

CILJ: Napraviti analizu studija koje su se bavile prevencijom i ranim otkrivanjem karcinoma debelog crijeva u vrijeme pandemije COVID-19.

METODE: Korištenjem ključnih riječi provedena je elektronska pretraga u bazama podataka PubMed i Google znalac. U analizu su uključeni izvorni znanstveni, stručni i pregledni radovi napisani na hrvatskom i engleskom jeziku. Iz analize su isključene duplicirane studije i studije koje su se bavile prevencijom i ranim otkrivanjem karcinoma debelog crijeva $\mathrm{u}$ vremenu prije pojave pandemije COVID-19.

REZULTATI: U Hrvatskoj su ove godine napravljene 15443 kolonoskopije dok je u istom razdoblju prošle godine napravljeno njih 22638. Odaziv na tjedne preglede kolonoskopijom u Sjedinjenim Američkim Državama je pao za 86 \% odnosu na prvo polugodište 2019. godine. Broj tjednih kolonoskopija u Velikoj Britaniji je pao za oko 12 \%, dok je broj novootkrivenih karcinoma opao za oko 58 \%. U Kini je zabilježen pad broja obavljenih kolonoskopija i povećanje broja otkrivenih karcinoma debelog crijeva u kasnijem stadiju.

ZAKLJUČAK: Broj kolonoskopija i odaziva na programe ranog otkrivanja karcinoma debelog crijeva je pao u vrijeme pandemije COVID-19. Odgađanje ili otkazivanje preventivnih pregleda može dovesti do odgode liječenja i uspostavljanja dijagnoze u kasnijem stadiju bolesti.

Ključne riječi: prevencija, rano otkrivanje, karcinom debelog crijeva, COVID-19

Key words: prevention, screening, colon cancer, COVID-19

Autor za korespondenciju:Darjan Franjić, mag. rad. techn., doktorand

Email: darjan.franjic@fzs3.sum.ba 


\section{UVOD}

Karcinom debelog crijeva jedan je od vodećih karcinoma koji uzrokuje smrt (1). Podjednako se pojavljuje u žena i u muškaraca (2). Povećanju stope preživljavanja od karcinoma debelog crijeva najviše doprinose mjere prevencije. Osnovna uloga primarnih mjera prevencije karcinoma debelog crijeva je smanjenje ili sprječavanje djelovanja bitnih čimbenika u nastanku neoplastičnih promjena. Mjere sekundarne prevencije su se pokazale najučinkovitijima u probiru karcinoma debelog crijeva te su izrazito bitne u pravovremenom otkrivanju novotvorina u ograničenom i kurativnom stadiju. Važnost prevencije i rane dijagnoze karcinoma debelog crijeva dodatno je poduprta izrazito visokim stupnjem mortaliteta od ove bolesti, ali i mogućnošću njezine redukcije (3). Osnovne metode koje se koriste u prevenciji karcinoma debelog crijeva su: testovi kojima se otkrivaju tragovi krvi u stolici koji se ne mogu opaziti okom kao što je fekalno imunokemijski test (FIT) i pregledi kojima se izravno analiziraju morfološke promjene sluznice debelog crijeva, a koji uključuju endoskopski pregled debelog crijeva (kolonoskopiju) (4). Budući da većina karcinoma debelog crijeva nastaje malignom alteracijom adenomatonih polipa, razvijeni su brojni programi probira s ciljem povećanja detekcije polipa i karcinoma u ranom stadiju. Kolonoskopija je metoda koja predstavlja zlatni standard u ranom otkrivanju karcinoma debelog crijeva (5). Pojava pandemije koronavirusne bolesti 2019 (engl. Coronavirus disease 2019, COVID-19) uzrokovane novim koronavirusom ili virusom teškog respiratornog sindroma (engl. Severe Acute Resporatory Sindrome Coronavirus-2, SARS-CoV-2) svojom virulencijom predstavlja izazov za funkcioniranje zdravstvenih sustava diljem svijeta, pa tako i programa ranog otkrivanja karcinoma debelog crijeva (6). Bolest se širi izravnim kontaktom, kapljičnom infekcijom (7). S obzirom da da je virus SARS-CoV-2 izoliran u slini, stolici i urinu moguć je i prijenos fekalno-oralnim putem (8). Stoga se preventivne mjere širenja infekcije uglavnom odnose na sprječavanje bliskih socijalnih kontakata u populaciji. Takve mjere otežavaju preventivne aktivnosti i rano otkrivanje karcinoma debelog crijeva u vrijeme pandemije COVID-19 (9). To naročito vrijedi za onkološke bolesnike koji zbog imunokompromitiranog imuniteta predstavljaju iznimno osjetljivu populaciju jer prisustvo maligne bolesti i terapija mogu smanjiti sposobnost organizma da se izbori sa infekcijom koronavirusa (10).

Cilj je napraviti analizu studija koje su se bavile prevencijom i ranim otkrivanjem karcinoma debelog crijeva u vrijeme pandemije COVID-19.

\section{MATERIJALI I METODE}

Pretraživana je literatura koja se bavila prevencijom i ranim otkrivanjem karcinoma debelog crijeva u vrijeme pandemije COVID-19. Provedena je elektronska pretraga u bazama podataka PubMed i Google znalac korištenjem ključnih riječi: 'Prevention,' 'Screening' 'Colorectal cancer,' 'COVID-19'. Kriteriji uključenja pronađenih studija u analizu bili su: izvorni znanstveni, stručni i sustavni pregledni rad. Analizirani su radovi napisani na engleskom jeziku. Sažetci napisani na engleskom jeziku članaka koji su izvorno napisani na kineskom jeziku su također uključeni u analizu. Iz analize su isključene duplicirane studije i studije koje su se bavile prevencijom karcinoma debelog crijeva u vremenskom razdoblju prije pojave pandemije COVID-19. Pretraga literature je obavljena korištenjem „Booleanove logike“. Booleovi operatori 'AND', 'OR' ili 'NOT' postavljeni su između pojmova za pretraživanje. Prilikom postavke operatora 'OR' pronađeno je 7,348,088 rezultata. Postavljanjem operatora 'NOT' pronađeno je 36,926 rezultata. Postavljanjem operatora 'AND' izdvojena su 22 članka koja su sadržavala samo odabrane pojmove (COVID-19, karcinom debelog crijeva, prevencija, „screening“). Izvršena je analiza 10 radova koji su zadovoljavali kriterij uključenja. Pretraživanjem baze podataka Google znalac korištenjem navedenih ključnih riječi pronađeno je 3,580 rezultata od kojih je izvršena analiza pet radova koji su zadovoljavali kriterij uključenja. Literatura je pretraživana u razdoblju između srpnja i rujna 2020. godine. Svi analizirani radovi su objavljeni u 2020. godini. 


\section{REZULTATI}

Autori najnovijih istraživanja ističu da je za provedbu programa ranog otkrivanja karcinoma debelog crijeva ključno osigurati uvjete koji će onemogućiti širenje COVID-19 bolesti. Mnoge države bilježe pad broja odaziva na preventivne preglede kolonoskopijom. U hrvatskim bolnicama su u prvom polugodištu 2020. godine napravljene 15443 kolonoskopije, za trećinu manje nego u istom razdoblju lani, kada ih je bilo 22638. Iz Hrvatskog gastroenterološkog društva upozoravaju da je zbog epidemije koronavirusa na $20 \%$ smanjen odaziv na Nacionalni program ranog otkrivanja raka debelog crijeva. Naročito je vidljiv pad broja kolonoskopija koje su posljedica testiranja u okviru provedbe Nacionalnog programa, kada se osobe kod kojih se utvrdi pozitivan test na nevidljivu krv u stolici upućuje na kolonoskopski pregled u bolnicu. U prvih pet mjeseci prošle godine napravljeno je 2281 takvih kolonoskopija, a ove godine $\mathrm{u}$ istom razdoblju 1472 (11). Na našim prostorima je provedeno nekoliko studija koje su se bavile etiologijom COVID-19 bolesti i načinima očuvanja od stresa za vrijeme pandemije koronavirusa te one predstavljaju iznimno važne smjernice u prilagodbi pojedinca oboj izvanrednoj situaciji (12-14). Pretraživanjem baza podataka PubMed i Google znalac nije pronađena studija koja se bavila odazivom na preglede kolonoskopijom $\mathrm{u}$ bosanskohercegovačkim bolnicama tijekom pandemije COVID-19. U svijetu su provedene brojne studije koje su se bavile prevencijom i ranim otkrivanjem karcinoma debelog crijeva tijekom pandemije COVID-19. Rezultati analiziranih studija su vidljivi u Tablici 1.

Tablica 1. Prikaz studija uključenih u analizu.

\begin{tabular}{|c|c|c|c|c|}
\hline $\begin{array}{l}\text { Autori; mjesec i godi- } \\
\text { na izdavanja }\end{array}$ & Vrsta istraživanja & Baza podataka & Država & Rezultat \\
\hline $\begin{array}{l}\text { Balzora S i sur.; sr- } \\
\text { panj } 2020 .\end{array}$ & Stručni rad & PubMed & *SAD & $\begin{array}{l}\text { Aktivnosti otkazivanja preventivnih } \\
\text { pregleda za vrijeme pandemije } \\
\text { COVID-19 mogu ugroziti dugo- } \\
\text { godišnje napore onkološke struke } \\
\text { u smanjenju stope smrtnosti u ne- } \\
\text { dovoljno razvijenim populacijama. }\end{array}$ \\
\hline $\begin{array}{l}\text { Bhandari P i sur.; } \\
\text { kolovoz 2020. }\end{array}$ & Sustavni pregledni članak & Google znalac & $\begin{array}{l}\text { Velika } \\
\text { Britanija }\end{array}$ & $\begin{array}{l}\text { Prilikom pripreme } \mathrm{i} \text { izvođenja endo- } \\
\text { skopije treba voditi računa o zaštiti } \\
\text { pacijenta, medicinskog osoblja i } \\
\text { endoskopske prostorije od širenja } \\
\text { infekcije. }\end{array}$ \\
\hline $\begin{array}{l}\text { Del Vecchio Blanco } \\
\text { G i sur.; lipanj } 2020 .\end{array}$ & Stručni rad & PubMed & Italija & $\begin{array}{l}\text { Smanjenje odaziva u organiziranom } \\
\text { probiru karcinoma debelog crije- } \\
\text { va tijekom pandemije COVID-19 } \\
\text { može dovesti do odgode liječenja ili } \\
\text { uspostavljanja dijagnoze u kasnijem } \\
\text { stadiju bolesti. }\end{array}$ \\
\hline $\begin{array}{l}\text { D’Ovidio V i sur.; sr- } \\
\text { panj } 2020 .\end{array}$ & $\begin{array}{l}\text { Izvorni znanstveni rad: } \\
\text { retrospektiva kohortna } \\
\text { studija }\end{array}$ & Google znalac & Italija & $\begin{array}{l}\text { Od } 137 \text { osoba koje su pozvane na } \\
\text { kolonoskopski pregled u vremenu } \\
\text { zabrane kretanja, njih } 60 \text { se odaz- } \\
\text { valo. }\end{array}$ \\
\hline $\begin{array}{l}\text { Gralnek IM i sur.; } \\
\text { svibanj 2020. }\end{array}$ & Stručni rad & Google znalac & Izrael & $\begin{array}{l}\text { Proces provođenja pregleda kolo- } \\
\text { noskopijom treba se prilagoditi pre- } \\
\text { ventivnim mjerama u svrhu sprječa- } \\
\text { vanja širenja zaraze. }\end{array}$ \\
\hline
\end{tabular}


Franjić D, Marijanović I. Prevencija i rano otkrivanje karcinoma debelog crijeva u vrijeme pandemije covid-19. Zdravstveni glasnik. 2020;6(2):96-104.

\begin{tabular}{|c|c|c|c|c|}
\hline $\begin{array}{l}\text { Gupta i Lieberman; } \\
\text { srpanj } 2020 .\end{array}$ & Stručni rad & PubMed & & $\begin{array}{l}\text { Postotak odaziva na tjedne kolo- } \\
\text { noskopske preglede u SAD-u je } \\
\text { opao za } 86 \% \text { od pojave COVID- } 19 \\
\text { pandemije. }\end{array}$ \\
\hline $\begin{array}{l}\text { Luo i Zhong; ožujak } \\
2020 .\end{array}$ & Stručni rad & PubMed & Kina & $\begin{array}{l}\text { Pregled kolonoskopijom poveća- } \\
\text { va rizik unakrsne zaraze s virusom } \\
\text { SARS-CoV- } 2 \text {. }\end{array}$ \\
\hline $\begin{array}{l}\text { Maida M i sur.; kolo- } \\
\text { voz } 2020 .\end{array}$ & $\begin{array}{l}\text { Izvorni znanstveni rad: } \\
\text { prospektivna studija }\end{array}$ & PubMed & Italija & $\begin{array}{l}\text { Zabilježene su značajne promjene u } \\
\text { protokolu provođenja kolonoskop- } \\
\text { ije i u manjem broju odaziva na } \\
\text { preglede kolonoskopijom od pojave } \\
\text { pandemije COVID- } 19 \text {. }\end{array}$ \\
\hline $\begin{array}{l}\text { Nodora JN i sur.; } \\
\text { kolovoz } 2020 .\end{array}$ & Stručni rad & PubMed & SAD & $\begin{array}{l}\text { Treba uložiti u strategije prevencije } \\
\text { karcinoma debelog crijeva te podr- } \\
\text { žati nepristrana i prilagodljiva Tele- } \\
\text { Health rješenja. }\end{array}$ \\
\hline $\begin{array}{l}\text { Repici A i sur.; tra- } \\
\text { vanj } 2020 .\end{array}$ & $\begin{array}{l}\text { Izvorni znanstveni } \mathrm{rad}: \\
\text { prospektivna studija }\end{array}$ & Google znalac & Italija & $\begin{array}{l}\text { Od ukupno } 41 \text { jedinice za endo- } \\
\text { skopiju, u } 40 \text { jedinica je zabilježeno } \\
\text { značajno smanjenje odaziva na en- } \\
\text { doskopske preglede. }\end{array}$ \\
\hline $\begin{array}{l}\text { Ren X i sur.; travanj } \\
2020 .\end{array}$ & Stručni rad & PubMed & Kina & $\begin{array}{l}\text { Simptome uzrokovane karcinomom } \\
\text { debelog crijeva treba razlikovati od } \\
\text { nekih karakteristika povezanih s } \\
\text { COVID-19 pandemijom. }\end{array}$ \\
\hline $\begin{array}{l}\text { Rutter MD i sur.; sr- } \\
\text { panj } 2020 .\end{array}$ & Stručni rad & PubMed & $\begin{array}{l}\text { Velika Bri- } \\
\text { tanija }\end{array}$ & $\begin{array}{l}\text { Broj tjednih endoskopskih pregleda } \\
\text { u Velikoj Britaniji je u vrijeme pan- } \\
\text { demije COVID-19 smanjen za oko } \\
12 \% \text {, dok je broj novootkrivenih } \\
\text { karcinoma smanjen za oko } 58 \% \text {. }\end{array}$ \\
\hline $\begin{array}{l}\text { Vecchione L i sur.; } \\
\text { svibanj } 2020\end{array}$ & Stručni rad & PubMed & Italija & $\begin{array}{l}\text { Određivanje dijagnoze i terapije } \\
\text { karcinoma debelog crijeva preven- } \\
\text { tivnim metodama je vrlo važno za } \\
\text { održavanje funkcionalnosti zdravst- } \\
\text { venih sustava. }\end{array}$ \\
\hline $\begin{array}{l}\text { Zhu L i sur.; travanj } \\
2020 .\end{array}$ & $\begin{array}{l}\text { Izvorni znanstveni rad: } \\
\text { retrospektivna kohortna } \\
\text { studija }\end{array}$ & PubMed & Kina & $\begin{array}{l}\text { Broj preventivnih endoskopskih } \\
\text { pregleda u vrijeme pandemije } \\
\text { COVID - } 19 \text { je opao u odnosu na } \\
\text { prvo polugodište } 2019 \text {. godine. Sto- } \\
\text { pa detekcije karcinoma debelog cri- } \\
\text { jeva u kasnijem stadiju je značajno } \\
\text { povećana. }\end{array}$ \\
\hline
\end{tabular}

*Sjedinjene Američke Države

\section{RASPRAVA}

Dosadašnja istraživanja pokazuju da je u vrijeme pandemije COVID-19 značajno smanjen odaziv na kontrolne i preventivne preglede u sklopu nacionalnih programa za rano otkrivanje karcinoma (15). S obzirom da ishod liječenja karcinoma debelog crijeva uvelike ovisi o dijagnozi bolesti u što ranijem stadiju kao i o pravovremeno započetoj terapiji, to je vrlo zabrinjavajući podatak. Stručnjaci upozoravaju da prekidi u provođenju prevencijskih pro- grama karcinoma debelog crijeva mogu uzrokovati dijagnozu bolesti u uznapredovanom stadiju. Stoga nadležne institucije s pravom iskazuju bojazan za povećanje stope pojavnosti karcinoma debelog crijeva u vrijeme pandemije COVID-19 kao i nakon njenog završetka (16). Odgode rutinskih preventivnih pregleda zbog prevencije širenja zaraze koronavirusom dovele su do značajnog povećanja broja otkazanih pregleda kolonoskopijom u Sjedinjenim Američkim Državama (SAD). Pretpostavlja se da će 
zbog takvih aktivnosti doći do značajnog povećanja broja oboljelih od karcinoma debelog crijeva. Iako je ova privremena odgoda bila nužna za suzbijanje infekcije COVID-19, svjetska gastroenterološka društva i stručnjaci iskazuju bojazan o prevelikom utjecaju pandemije na slab odaziv na programe ranog karcinoma debelog crijeva, naročito u zajednicama u kojima su morbiditet i smrtnost od karcinoma debelog crijeva najviše izraženi. Stručnjaci upućuju na mogućnost ugrožavanja funkcionalnosti zdravstvenih sustava zbog prevelikog broja novootkrivenih karcinoma debelog crijeva (17). Stoga onkološke ustanove moraju nastaviti s funkcioniranjem i restrukturiranjem u vrijeme pandemije, služeći se postupcima i dijagnostičke metodama kojima raspolažu (18). Smatra se da veliki broj pacijenata odgađa preventivne i kontrolne preglede zbog straha od zaraze koronavirusom. U današnje vrijeme sva se pažnja usmjerila na borbu s pandemijom COVID-19 zbog čega može doći do zanemarivanja drugih bolesti kao što je karcinom debelog crijeva koje mogu biti opasnije po život. Zbog toga zdravstveni djelatnici moraju raditi na osvješćivanju pacijenata o važnosti obavljanja preventivnih i kontrolnih pregleda.

Pojedini autori ističu da bi se u vrijeme pandemije COVID-19 strategije prevencije i liječenja karcinoma debelog crijeva trebale razlikovati od standardnih. Prema njima, potrebno je uskladiti protokol s preporukama nacionalnih civilnih stožera u svrhu sprječavanja širenja COVID-19 infekcije (19). Na taj način će i pacijenti i zdravstveni djelatnici biti sigurniji. Naročito je bitno zaštititi onkološke pacijente, jer izvješća stručnjaka sugeriraju da COVID-19 može biti posebno smrtonosan za onkološke bolesnike. Naročito osjetljivu populaciju predstavljaju pacijenti koji se liječe kemoterapijom. U vrijeme pandemije COVID-19 onkološki bolesnici suočeni su s dvostrukim rizikom. Naime, u onkoloških bolesnika postoji veći rizik od razvoja težeg oblika bolesti COVID-19. Nadalje, zbog straha od zaraze često odgađaju odlazak u medicinsku ustanovu na preventivni pregled (20). Američko udruženje za borbu protiv karcinoma očekuje da će se ove godine u Sjedinjenim Američkim Državama dnevno dijagnosticirati gotovo 5000 novih slučajeva karcinoma zbog smanjenja broja preventivnih pregleda (21). Napredovanje karcinoma debelog crijeva zbog kašnjenja $\mathrm{u}$ provođenju kolonoskopskih pregleda u vrijeme pandemije COVID-19 može značajno utjecati na dugoročno preživljavanje pacijenata (22). Stručnjaci preporučuju stvaranje uvjeta za provedbu slanja fekalnih imunokemijskih testova poštom, s ciljem osiguravanja epidemioloških mjera (23). Stvaranje uvjeta za što bezbrižnije provođenje kolonoskopija izrazito je važno u državama u kojima kolonoskopija predstavlja glavnu metodu probira karcinoma debelog crijeva $(24,25)$. Obustava preventivnih pregleda kolonoskopijom utjecala je i na druge metode probira karcinoma debelog crijeva. Aktivnosti odgađanja preventivnih pregleda dovele su do toga da je visoko rizičnim pacijentima onemogućeno uspostavljanje dijagnoze sa sigurnošću jer ne postoji učinkovitija metoda probira karcinoma debelog crijeva od kolonoskopije. Poznato je da oko 90 \% karcinoma debelog crijeva nastaje iz polipa, te da rano otkrivanje i uklanjanje polipa smanjuje broj umrlih. Obustavom preventivnih pregleda kolonoskopijom u vrijeme rano otkrivanje i uklanjanje polipa je onemogućeno. Preventivne neaktivnosti naročito su štetne za pacijente koji su preživjeli karcinom debelog crijeva te kojima se preporučuju preventivni pregledi kolonoskopijom kao dio smjernica za praćenje onkoloških bolesnika nakon završetka terapije (26). Pandemija COVID-19 imala je veliki utjecaj na smanjenje odaziva na endoskopske preglede i u Velikoj Britaniji gdje su zabilježene i značajne izmjene u protokolu prilikom obavljanja endoskopskih pregleda kao što je duljina trajanja pretrage (27). Bez obzira na mnoge poteškoće i komplikacije u protokolu, stručnjaci nalažu da se endoskopski pregledi u vrijeme pandemije COVID-19 moraju obavljati uz poštivanje epidemioloških mjera (28). Teško je procijeniti do kada će prisutnost COVID-19 bolesti utjecati na aktivnosti otkazivanja preventivnih pregleda kolonoskopijom (29). Stručnjaci ističu da, kolikogod pandemija trajala, zanemarivanje i odbijanje odaziva na programe ranog otkrivanja karcinoma debelog crijeva treba što prije zaustaviti (30). Iako se neke odgode preventivnih pregleda zbog ograničenja resursa i sprječavanja širenja zaraze moraju 
prihvatiti, u nekim slučajevima se dosadašnja praksa može i/ili treba izmijeniti i prilagoditi novonastaloj situaciji u svrhu sprječavanja kašnjenja u uspostavljanju dijagnoze (31). Istraživačka skupina koja se bavi utjecajem pandemije COVID-19 na prevenciju i liječenje karcinoma debelog crijeva navodi da je potrebno obuhvatiti i proučiti što je više moguće zdravstvenih modela kako bi se došlo do najučinkovitijeg pristupa u provođenju preventivnih metoda i programa ranog otkrivanja karcinoma debelog crijeva (32). Mnogi autori navode da manji broj odaziva na programe ranog otkrivanja karcinoma debelog crijeva utječe na povećanje stope smrtnosti od ove bolesti (33). Takav scenarij mogao bi ugroziti dugogodišnji rad znanstvenika i stručnjaka diljem svijeta na povećanju stope preživljavanja oboljelih od karcinoma debelog crijeva, ponajprije unaprjeđivanjem metoda liječenja i/ili uspostavljanjem rane dijagnoze. Rezultati istraživanja koje je provedeno u Italiji u travnju ove godine pokazuje da je gotovo u svakoj endoskopskoj jedinici koja je istraživana zabilježen prijem barem jednog pacijenta s pozitivnim testom na SARS-CoV-2 (34). To pokazuje da je medicinsko osoblje koje obavlja endoskopske preglede naročito ugroženo od širenja zaraze te da se posebna pažnja treba posvetiti uspostavljanju mjera koje će doprinijeti smanjenju mogućnosti od širenja zaraze. Ohrabrujuće su analize većine dosadašnjih studija koje pokazuju da se kolonoskopija i u vrijeme pandemije COVID-19 pokazala sigurnom i učinkovitom metodom probira. Ovaj navod potkrjepljuje podatak da u talijanskim bolnicama tijekom i nakon pregleda kolonoskopijom nije zabilježen nijedan slučaj unakrsne zaraze (35). Grupa svjetskih gastroenteroloških stručnjaka je primjenom Delphi tehnike donijela konsenzus o provođenju endoskopskih pregleda u vrijeme pandemije COVID-19. Donijete odluke se odnose na poštivanje preventivnih mjera u svrhu sprječavanje širenja infekcije (testiranje, poštivanje održavanja tjelesne distance tjedan dana prije pregleda), održavanje prostorije u kojoj se izvodi endoskopski pregled (redovita dezinfekcija), vođenje brige o zaštiti medicinskog osoblja (obavezno nošenje zaštitne maske i rukavica od strane pacijenta i zdravstvenog djelatnika, redovito testira- nje), ponašanje pacijenata i medicinskog osoblja u skladu s preporukama nacionalnog civilnog stožera nakon obavljenog endoskopskog pregleda te redovita sterilizacija endoskopskih uređaja i sondi (36).

Ograničenje ovog rada predstavlja analiza samo onih istraživanja koji su objavljeni na engleskom jeziku. Dodatno ograničenje predstavlja analiza samo javno dostupnih istraživanja. U svrhu povećanja znanja o ranom otkrivanju i prevenciji karcinoma debelog crijeva u vrijeme pandemije COVID-19 potrebno je napraviti sustavni pregledni rad u kojem će biti otklonjen bias prema engleskom jeziku s uključenim rezultatima neobjavljenih istraživanja (37).

\section{ZAKLJUČAK}

Broj kolonoskopija i odaziva na programe ranog otkrivanja karcinoma debelog crijeva je pao u vrijeme pandemije COVID-19. Veliki broj pacijenata odgađa odlazak u bolnicu na preventivne preglede zbog bojazni od zaraze koronavirusom. Za povećanje broja odaziva ključan je pronalazak modela koji će osigurati što bolji odaziv, kontinuitet i kvalitetu programa ranog otkrivanja karcinoma debelog crijeva u vrijeme pandemije COVID-19. Kolonoskopija se mora provoditi uz poštivanje epidemioloških mjera, kao što je redovita dezinfekcija i sterilizacija kolonoskopa, nošenje zaštitnih maski i rukavica od strane pacijenta i zdravstvenih djelatnika te socijalna distanca. Stručnjaci koji se bave onkološkim bolestima upozoravaju da će jedna od posljedica pandemije COVID-19 biti veliki porast pojavnosti karcinoma pa pozivaju građane da ne zanemaruju simptome te da se odazivaju na preventivne preglede i pretrage. Odgađanje ili otkazivanje preventivnih pregleda može dovesti do odgode liječenja i uspostavljanja dijagnoze u kasnijem stadiju bolesti. Podređivanje samo COVID-19 bolesti može dovesti do zanemarivanja drugih bolesti kao što je karcinom debelog crijeva koje s vremenom mogu izazvati mnogo veće zdravstvene probleme te dovesti u pitanje funkcioniranje zdravstvenih sustava diljem svijeta. 


\section{LITERATURA}

1. Franjić D, Marijanović I, Babić D. Karcinom debelog crijeva i rezilijencija. Zdravstveni glasnik [Internet]. 2019 [pristupljeno 01.10.2020.];5(2):66-74. Dostupno na: https:// hrcak.srce.hr/228915

2. Vrdoljak E, Lovasić-Belac I, Kusić Z, Gugić D, Juretić A. Klinička onkologija: Rak debeloga crijeva. 3. obnovljeno i dopunjeno izdanje. Zagreb: Medicinska naklada, 2018.

3. Štimac D, Katičić M, Kujundžić M, Ljubičić N, Poropat G, Bokun T. Značaj ranog otkrivanja raka debelog crijeva. Medicina Fluminensis [Internet]. 2008 [pristupljeno 24.09.2020.];44(1):7-15. Dostupno na: https:// hrcak.srce.hr/25943

4. Ljubičić N. Otkrijte rak debelog crijeva na vrijeme. Pliva zdravlje [Internet]. 2017 [pristupljeno 28.09.2020.].

5. Dostupno na: https://www.plivazdravlje.hr/aktualno/clanak/29649/Otkrijte-rak-debelog-crijeva-na-vrijeme.html

6. Čavlina M, Rustemović N. Advances in endoscopic diagnosis of colorectal cancer. Rad Hrvatske akademije znanosti i umjetnosti. Medicinske znanosti [Internet]. 2017 [pristupljeno 24.09.2020.];(530=44):55-64.

7. Dostupno na: https://doi.org/10.21857/y26kecvzl9

8. Lui RN, Wong SH, Sánchez-Luna SA, Pellino G, Bollipo S, Wong MY, et al. Overview of guidance for endoscopy during the coronavirus disease 2019 pandemic. J Gastroenterol Hepatol. 2020;35(5):749-759. doi:10.1111/jgh.15053

9. Guan W, Ni Z, Hu Y, Liang W, Ou C, He J, et al. Clinical characteristic of Coronavisus disease 2019 China. N Engl J Med [Internet]. 2020 [pristupljeno 10.09.2020.];1-13.

10. Dostupno na: https://www.nejm.org/doi/ full/10.1056/NEJMoa2002032

11. Chan JYK, Wong EWY, Lam W. Practical aspects of otolaryngologic clinical services during the 2019 novel Coronavirus epidemic. JAMA Otolaryngol Head Neck Surg. 2020;382:17081720.
12. Robilotti EV, Babady NE, Mead PA. Determinants of COVID-19 disease severity in patients with cancer. Nat Med 2020;26:1218-1223.

13. Lui RN, Wong SH, Sánchez-Luna SA, Pellino G, Bollipo S, Wong MY, et al. Overview of guidance for endoscopy during the coronavirus disease 2019 pandemic. J Gastroenterol Hepatol. 2020;35(5):749-759.

14. Hrvatsko gastroenterološko društvo. Manje kolonoskopija zbog epidemije koronavirusa. PLIVAZdravlje [Internet]. 2020 [pristupljeno 01.10.2020]. Dostupno na: https://www.plivazdravlje.hr/vijesti/clanak/34207/Manje-kolonoskopija-zbog-epidemije-koronavirusa.html

15. Babić D, Babić M. Kako se sačuvati od stresa za vrijeme pandemije koronom. Zdravstveni glasnik [Internet]. 2020 [pristupljeno 22.09.2020.];6(1):25-32.

16. Dostupno na: https://hrcak.srce.hr/239141

17. Vasilj I, Ljevak I. Epidemiološke karakteristike COVID-a 19. Zdravstveni glasnik [Internet]. 2020 [pristupljeno 11.09.2020.];6(1):9-18.

18. Dostupno na: https://hrcak.srce.hr/239141

19. Vasilj I, Herceg K, Čović I, Šantić M, Curlin M, Ljevak I, et al. Determinants of the COVID-19 pandemic in the West Hercegovina canton. Psychiatria Danaubina. 2020;32(Suppl 2):221-225.

20. Al-Shamsi HO, Alhazzani W, Alhuraiji A, Coomes EA, Chemaly RF, Aluhanna M, et al. A practical approach to the management of cancer patients during the novel coronavirus disease 2019 (COVID-19) pandemic: an International Collaborative Group. Oncologist. 2020;25(6):e936-e945.

21. Del Vecchio Blanco G, Calabrese E, Biancone L, Monteleone G, Paoluzi OA. The impact of COVID-19 pandemic in the colorectal cancer prevention. Int J Colorectal Dis. 2020;1-4.

22. Balzora S, Issaka RB, Anyane-Yeboa A, Gray DM 2nd, May FP. Impact of COVID-19 on colorectal cancer disparities and the way. Gastrointest Endosc. 2020;S0016-5107(20)34468-0.

23. Vecchione L, Stintzing S, Pentheroudakis G, Douillard JY, Lordick F. ESMO management and treatment adapted recommendations in the 
Franjić D, Marijanović I. Prevencija i rano otkrivanje karcinoma debelog crijeva u vrijeme pandemije covid-19. Zdravstveni glasnik. 2020;6(2):96-104.

COVID-19 era: colorectal cancer. ESMO Open. 2020;5(Suppl 3):e000826.

24. Ren X, Chen B, Hong Y, Liu W, Jiang Q, Yang J, et al. The challenges in colorectal cancer management during COVID-19 epidemic. Ann Transl Med. 2020;8(7):498.

25. Kutikov A, Weinberg DS, Edelman MJ, Horwitz EM, Uzzo RG, Fisher RI. A war on two fronts: cancer care in the time of COVID-19. Ann Intern Med. 2020;172(11):756-758.

26. Liang W, Guan W, Chen R, Wang W, Li J, Xu K, et al. Cancer patients in SARS-CoV-2 infection: a nationwide analysis in China. Lancet Oncol. 2020;21:335-337.

27. Sud A, Jones ME, Broggio J, Loveday C, Torr B, Garret A, Nicol DL, et al. Collateral damage: the impact on outcomes from cancer surgery of the COVID-19 pandemic. Ann Oncol. 2020;31(8):1065-1074.

28. Nodora JN, Gupta S, Howard N, et al. The COVID-19 pandemic: identifying adaptive solutions for colorectal cancer screening in underserved communities. J Natl Cancer Inst. 2020;djaa117.

29. Gupta S, Lieberman D. Screening and surveillance colonoscopy and COVID-19: avoiding more casualties. Gastroenterology. 2020;S00165085(20)34932-5.

30. Epic Health Research Network. Delayed cancer screenings [Internet]. 2020 [pristupljeno 22.09.2020.]. Dostupno na: https://ehrn.org/ delays-in-preventivecancer-screenings-during-covid 19-pandemic/

31. Gupta S, Lieberman D, Anderson JC, Burke CA, Dominitz JA, Kaltenbach T, et al. Recommendations for follow-up after colonoscopy and polypectomy: a consensus update by the US multi-society task force on colorectal cancer. Gastroenterology. 2020;158(4):1131-1153.

32. Rutter MD, Brookes M, Lee TJ, Rogers P, Sharp L. Impact of the COVID-19 pandemic on UK endoscopic activity and cancer detection: a National Endoscopy Database Analysis. Gut. 2020;gutjnl-2020-322179.

33. Zhu L, Cai MY, Shi Q, Wang P, Li QL, Zhong YS, et al. Analysis of selective endoscopy results during the epidemic of coronavirus disease 2019 (COVID-19). Zhonghua Wei Chang Wai Ke Za Zhi. 2020;23(4):327-331.

34. Maida M, Sferrazza S, Savarino E, Ricciardiello L, Repici A, Morisco F, et al. Impact of the COVID-19 pandemic on Gastroenterology Divisions in Italy: A national survey. Dig Liver Dis. 2020;52(8):808-815.

35. Issaka RB, Somsouk M. Colorectal cancer screening and prevention in the COVID-19 Era. JAMA Health Forum [Internet]. 2020 [pristupljeno 21.09.2020.]. Dostupno na: https://jamanetwork.com/channels/health-forum/fullar$\underline{\text { ticle/2766137 }}$

36. Mirnezami R, Knowles J, Kar A, Glynne-Jones R. Preoperative radiotherapy for locally advanced rectal cancer during and after the COVID-19 pandemic. Br J Surg. 2020;107(8):e263.

37. CRC COVID research collaborative. Colorectal cancer services during the COVID-19 pandemic. Br J Surg. 2020;107(8):e255-e256.

38. Gralnek IM, Hassan C, Dinis-Ribeiro M. COVID-19 and endoscopy: implications for healthcare and digestive cancer screening. Nat Rev Gastroenterol Hepatol. 2020;17, 444-446.

39. Repici A, Pace F, Gabbiadini R, Colombo M, Hassan C, Dinelli M. Endoscopy units and the Coronavirus Disease 2019 outbreak: a multicenter experience from Italy. Gastroenterology. 2020;159:363-366.

40. D’Ovidio V, Lucidi C, Bruno G, Lisi D, Miglioresi L, Bazuro ME. Impact of COVID-19 pandemic on colorectal cancer screening program. Clin Colorectal Cancer. 2020:S1533-0028(20)30101-8.

41. Bhandari P, Subramaniam S, Bourke MJ, Alkandari A, Chiu PWY, Brown JF, et al. Recovery of endoscopy services in the era of COVID-19: recommendations from an international Delphi consensus. Gut Published Online First: $14 \mathrm{Au}-$ gust 2020. doi: 10.1136/gutjnl-2020-322329

42. Franić M, Dokuzović S, Petrak J. Sustavni pregled - podloga medicini utemeljenoj na znanstvenim spoznajama. JAHS. 2016; 2(2):113-120. 


\title{
PREVENTION AND EARLY DETECTION OF COLON CANCER DURING THE COVID-19 PANDEMIC
}

\author{
Darjan Franjić, ${ }^{1,2}$, Inga Marijanović1,2 \\ ${ }^{1}$ Clinic for Oncology, University Clinical Hospital Mostar \\ ${ }^{2}$ Faculty of Health Studies University of Mostar \\ 88000 Mostar, Bosnia and Herzegovina
}

\begin{abstract}
INTRODUCTION: High mortality rate of colon cancer indicates to the importance of prevention and early detection of this disease. The outbreak of the corona virus pandemic represents a challenge for the implementation of the early detection programs for colon cancer.

OBJECTIVE: Conduct an analysis of studies on prevention and early detection of colon cancer during the Covid-19 pandemic.

METHODS: We conducted a search of electronic databases PubMed and Google Scholar by keywords. The analysis included original research articles, and professional and review articles written in the Croatian and English language. The analysis excluded duplicate publications and studies on prevention and early detection of colon cancer prior to the Covid-19 pandemic.

RESULTS: There were 15,443 colonoscopy procedure performed in Croatia while in the same period of the previous year there were 22,636 colonoscopies. The number of weekly colonoscopy exams dropped by $86 \%$ in the United States in comparison to the first half of 2019. The number of colonoscopies dropped by $12 \%$ in Great Britain, while the number of newly diagnosed cancers dropped by 58\%. In China, there has been a decline in the number of colonoscopies performed and an increase in the number of detected colon cancers at a later stage.

CONCLUSION: The number of colonoscopies and responses to early detection programs for colon cancer has declined during the Covid-19 pandemic. Delay or cancelation of preventive examination may lead to postponed treatment and diagnosis at a later stage.

Key words: prevention, early detection, colon cancer, COVID-19
\end{abstract}

Correspondence:

Darjan Franjić, MA

E-mail: darjan.franjic@fzs3.sum.ba 